\title{
Some Contributions to the Physiography and Hydrography of North-East Borneo
}

\section{Author(s): I. A. Stigand}

Source: The Geographical Journal, Vol. 37, No. 1 (Jan., 1911), pp. 31-42

Published by: geographicalj

Stable URL: http://www.jstor.org/stable/1777577

Accessed: 25-06-2016 23:14 UTC

Your use of the JSTOR archive indicates your acceptance of the Terms \& Conditions of Use, available at

http://about.jstor.org/terms

JSTOR is a not-for-profit service that helps scholars, researchers, and students discover, use, and build upon a wide range of content in a trusted digital archive. We use information technology and tools to increase productivity and facilitate new forms of scholarship. For more information about JSTOR, please contact support@jstor.org.

The Royal Geographical Society (with the Institute of British Geographers), Wiley are collaborating with JSTOR to digitize, preserve and extend access to The Geographical Journal 


\section{SOME CONTRIBUTIONS TO THE PHYSIOGRAPHY AND HYDROGRAPHY OF NORTH-EAST BORNEO.*}

\section{By I. A. STIGAND.}

IN consideration of the comparatively little-known physiographical conditions in these parts of Borneo, the following contributions may be worthy of record. On the east coast, more especially, the physiographic associations of the rivers, together with the evidences which they display of former secular movements, present many interesting features, while records also exist of movements of a more rapid character. As the regions described have to be approached from the east coast, it is necessary to start, as it were, from the wrong end, the observations proceeding from the mouths of the rivers towards the interior. The district principally dealt with lies in the vicinity of the boundary between Dutch and British North Borneo on the east side, and is bounded, for the most part, by that long length of coast designated Sibuku or St. Lucia bay.

Commencing to the south of Sibuku bay, the coastal regions consist of an immense area of deltaic deposits-the combined products of the Sambakong and Sibuku rivers. The former river is one of the largest, with reference to its drainage area, in the northern portion of Borneo. The northern main branch of this river, or upper Sambakong, which flows down from the north, its basin expanding with an immense system of tributaries towards the north-west, drains a large portion-perhaps 2500 square miles-of South Central British North Borneo. On the west its basin extends to that of the Kinnabatangan and the upper tributaries of this river, while its north-western tributaries flow down from the watershed of the Padas and extend to no great distance from Tenom, which is on the railway from the west coast. Could boats be obtained on these upper sources, navigable portions of which are within comparatively easy access from Tenom, the transit of North Borneo from Brunei bay, by means of the Sambakong river, would not be a very difficult undertaking.

Continuing northwards, the next river is the Sibuku, the delta of which merges, with numerous ramifications, into that of the Sambakong river, and on the other side into the alluvial deposits of the Simmenggaris river. After at first trending in a westerly direction for some distance, the Sibuko also turns to the north-towards British North Borneo territory; its upper waters running parallel with the upper Sambakong on the west. This northerly trend is also taken by the principal tributaries of the next river-the Simmenggaris-also flowing into the sea in Dutch territory, some of the sources of which flow down from British North Borneo.

This hydrographic feature of these rivers, whereby the waterflow of a considerable portion of South Central British North Borneo is discharged through Dutch territory, has a not unimportant political significance, inasmuch as jungle produce (viz. rubber, rotan, resin, etc.) gathered in this British area, and transported by means of these rivers, is collected

* Map, p. 128. 
in Dutch Borneo. Although this is chiefly apparent in the case of the Sambakong, as the navigable portions of the Sibuku and Simmenggaris and their tributaries do not extend very far into British North Borneo, upper sources of these rivers proceed extensively into British North Borneo territory; moreover, the upper unnavigable parts of rivers and streams invariably form the routes for native paths into the interior connected with the farthest limits practicable for canoes.

To return to the Sibuku river, there are two principal mouths of this river-the Rooverstrek or Boekot river, flowing east and joining the sea not far from the mouth of the Sambakong; and the proper mouth of the Sibuku, flowing north-north-east, joining with the estuary of the Simmenggaris. The whole of the coastal region between the Sambakong and the Sibuku proper is composed of deltaic flats divided up by innumerable trusans or channels.

At the mouth of the Sibuku (Fig. 1), there is an island, composed of two hills joined by an alluvial tract-Tenelek I. (Fig. 2). The hill on the north-north-east extremity of the island is over 100 feet in height and bears evidence of being a remarkable recent upheaval, and remains of marine organisms which are denizens of the sea at the present day are found on the summit ; moreover, it exhibits a peculiar geological structure. This will be described in more detail in the sequel. The other hill on this island is a little higher and in shape suggestive of a volcanic cone. No exposures of rock could be found on its flanks, but outcrops of indurated strata occur on the shore in the vicinity. On the summit there is a pool always containing water. No recent marine remains were found on this hill.

On either side of the Sibuku mouth, other small isolated hills occur, many of a roughly conical form, as islands scattered in the alluvial sea. To the north-west of "New Hill" in the estuary of the Simmenggaris, occurs a very small island, composed of rock having a similar appearance to that of which "New Hill," is composed. It is called Plandok island, presumably on account of its smallness (Plandok-Malay $=$ mouse deer).

At a distance of some hours' paddling up the Sibuku is situated the Tidung village, designated by the same name as the river. On either side of the river, on the way to the village, other small hills occur. At the time of full moon, the Sibuku river is remarkable for having a bore. The advance of the wave up the river can be heard at some distance, thus offering a timely warning to the occupants of canoes.

We next come to the Simmenggaris river. Proceeding up the estuary, four commanding mountains are visible towards the west-north-west, and in the region of the sources of this river and of the Serudang. These mountains are, proceeding from north to south, named Blancus, Bukit Raya, Lobang Bakus (Lobang-Malay $=$ hole, Bakus-Tidung dialect $=$ pig), and Batu Maya.

On the south of the estuary of the Simmenggaris, there enters another river-the Sibakis-beyond the Sibuku, which drains a comparatively 
small yet considerable area between the lower Simmenggaris and Sibuku rivers, and entering the estuary of the Simmenggaris by a subsidiary estuary running north-north-east beyond which the river trends east towards the interior.

On the north side, after passing various delta arms, we come to the Kanduangan river: the estuarine channel of this river, after first trending north, turns at right angles, running east and west, and the channel receives three small rivers coming from the north, the first, named Kanduangan Kechil (Kechil-Malay = small), joining the channel at the bend, the other two, after joining, at the eastern extremity of the channel. These three small rivers or streams receive the drainage of

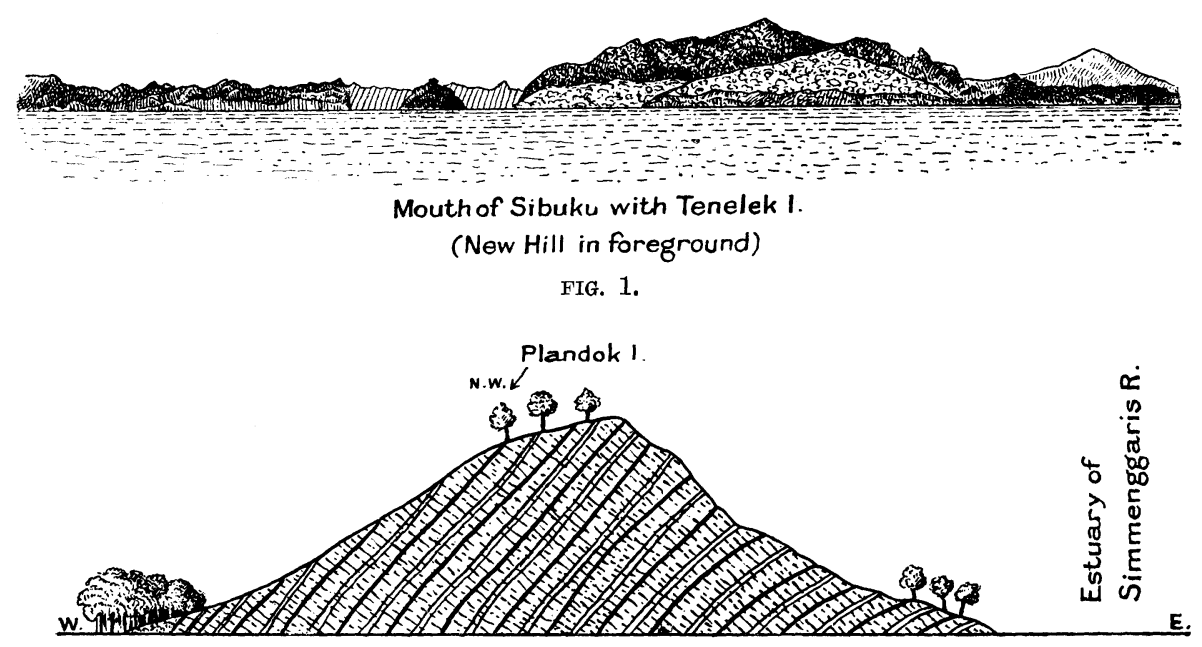

Profile of "New Hill" - Tenelek 1.

Mouth of SibukuRiver.

FIG. 2.

the greater portion of the country, consisting of hill lands, which lies between this part and the lower Serudang river. As will be seen, when we come to observe that river, the watershed in this area is situated comparatively close to the Serudang which runs in a narrow valley lying at some distance to the north of the boundary. In the Kanduangan the tidal limit is very high, proceeding some distance up its smaller tributaries, and it is, for the most part, a river of deposition.

The next tributary of the Simmenggaris is one that drains a large tract of country to the north-west, named the Seklean. Entering the Simmenggaris from the north and then bending towards the west, it trends on the whole north-west, flowing intermediate between the basins of the Serudang and the Semaja-a higher tributary of the Simmenggaris. Beyond, the Simmenggaris bends to the north (another tributary coming in from the west), but further on continues in a west-north-west direction,

No. I.-JANUARY, 1911.] 
until, at a distance of about 15 miles from the estuary, opposite the site of a deserted village, the Semaja river comes in from the north-north-east, although the average trend of this tributary is north-west. The Semaja takes its sources in British North Borneo, its upper basin adjoining the watershed of the basins of the Sui Sui-a south-west tributary of the Serudang-and the Tambulunan rivers, to the north. Coming down from this watershed, in a succession of cascades and rapids, and passing between the Seklian and Serudang river, it at length assumes a sinuous and less erosive form as it nears the Simmenggaris. At a short distance from its junction the Semaja receives a small river from the north, named the Jilompon, which receives a large part of the drainage from the watershed between the Semaja and the Seklean rivers. This watershed consists of a lofty range of hills, as also does that between the Seklean and the upper Serudang and Tambulunan rivers.

A few more windings of the Simmenggaris bring us to a Tidung village, situated within a pronounced sinuosity of the river which is fast developing into a "cut off." This village is known as the Semaja Kampong (Kampong-Malay = village) on account of it having originally been situated in the Semaja river. The chief of this village, having originally come, with his followers, from the Serudang, first settled about one and a half mile up the Semaja river, and then migrated to a position on the south bank of the Simmenggaris, opposite its junction with the Semaja, where the remnants of the dwellings can still be seen, before finally settling in the present position.

Beyond this village the Simmenggaris trends in an average west-northwest direction, flowing in a comparatively narrow valley, and becoming more erosive in its nature, although its tidal limit lies far beyond the village. Its basin is, for the most part, narrow, numerous small tributaries descending in cascades on either side, although there are a few fair-sized tributary streams, one of which, entering the main river from the south at a distance of about one hour's paddling above the village, is the Simmenggaris, the main river being known above this tributary as the Loesan. This curious application of the name of a larger river to one of its smaller tributaries is not an uncommon practice in these parts of Borneo, and exactly the same occurs in the case of the Serudang, the internal portion of which river is known as the Tambulunan above the junction of a small tributary from the south designated the Serudang.

The Loesan trends north-north-west to north-west, extending for a considerable distance towards the interior, where it descends in numerous rapids and cascades. There are habitations of Ulu Dusans and Tengaluns in the neighbourhood of its upper waters.

The formation in all this region consists of a series of sandstones, sandy shales, and shales containing numerous coal-seams, belonging to a low division of the Tertiary, generally dipping gently towards the south. This formation extends to the north rising in several monoclinal folds 
between the Simmenggaris and the Serudang, the horizons thus becoming lower as the latter river is approached from the former. Thare are numerous outcrops of coal in the region of the upper Simmenggaris, as also in the intermediate district between the latter river and the Serudang, many being of very fair quality and in seams of workable thickness. In the region of the lower parts and estuary of the Simmenggaris a more recent formation fills the basin, laid unconformably on the older Tertiary; in the vicinity of the Kanduangan river, this newer formation extends north as far as the boundary.

From the mouth of the Simmenggaris, the alluvium of the Simmenggaris delta-including an island named East Nonuekan-gradually narrows to a strip bordering the coast and hill lands between the Simmenggaris and Serudang rivers, which in turn gradually merges into the huge compound delta which is the combined product of the Serudang, Silompopon, and the Kalabakang rivers, and which extends as far as the north of Cowie harbour and is traversed by almost innumerable trusans or channels.

On account of the hydrographic feature to which reference has already been made, viz. that these large rivers flowing into the sea south of the boundary, with their tributaries, trend towards the north, the higher lands come nearer the coast in the region which is now approached, and there is thus more of physiographic interest to the observer from the east coast.

The Serudang and Silompopon rivers, at a short distance below their convergence, flow into a trusan or channel joining the two delta mouths, which are named respectively the Soadan and Solan.

A few windings of the Serudang, above its confluence with the Silompopon, bring one to a Tidung village of the same name. Above this the Serudang is a typical river of erosion. Its basin is relatively narrow, the watershed between it and the Simmenggaris being close to the Serudang; its lateral drainage being chiefly conducted in small streams which flow down in cascades into the Serudang. The basin, however, gradually expands towards the interior, where, dividing up into fair-sized tributaries, notably the Sui Sui and Tambulunan rivers, it drains a considerable area. The tidal limit in this river is situated at a distance of about 5 or 6 miles above the village. The valley in these parts is comparatively narrow, high hills rising on either side. At low tide there are rapids in the course of the river below the tidal limit. At this tidal limit the river falls over a hard bed of grit. Flowing over this hard stratum in a narrow and deep channel, the whole of the river is precipitated in considerable volume and force into a seething pool below, where the current, whirling round at low tide, has worn a deep recess in the sandstone outcrop on the right bank.

The Serudang passes along strata consisting for the most part of nearly horizontal sandstones, of various grades of induration, the harder ferruginous grits forming the waterfalls, rapids, etc. The strata, however, have on the whole, a gentle south-south-west dip, and, between the 
Serudang and Simmenggaris rivers, descend in a monoclinal fold, below which they are overlaid by the newer formation fillirg the lower basin of the Simmenggaris, and consisting of fluvatile deposits of white clay, sands, and shingle beds. Above this waterfall at the tidal limit the river-bed rapidly rises, passing over a succession of rapids over the harder strata, and rushing through gullies, for some miles inland. Above this strongly erosive portion of the river, which affords some fine scenery, the river again assumes a more placid aspect, passing on in many meanders for many miles towards the interior, and in these parts would be navigable even for small launches, were it not for occasional fallen tree-trunks. It is joined by two principal tributaries from the north, the Serom (coming in from the north-north-west) and the Serudang, the latter-a comparatively small tributary-as in the case of the Simmenggaris, taking the name of the main river.

Near the confluence of the small Serudang is situated a small settlement of Ulu Dusans, a primitive, but friendly tribe.

Beyond the junction the main river is known as the Tambulunan, and again becomes strongly erosive, rising to a considerable altitude over impassable rapids, until its convergence with the Sui Sui river. Here it bends round to a northerly direction, while the Sui Sui trends to the south-west. From their junction both rivers become navigable for native canoes. Further on the Sui Sui again becomes turbulent, splitting up, of course, into numerous tributaries, which take their rise in the watersheds with the Semaja and Sibuku rivers; while the Tambulunan river, also becoming of a strongly erosive form in its upper parts, flows down in rapids and cascades from the north.

Between the Serudang tributary and the Serom river rises a prominent elevation, known as Tidung Allah (Tidong-Tidung dialect $=$ mountain ; Allah-Malay = god). Its summit consists of a dip slope and escarpment, dipping gently towards the south-west. This may be the mythical Mount Creagh,* marked on the maps, but this name appears to be a very doubtful one.

We now come to consider the Silompopon river which, as mentioned above, converges with the Serudang river in the delta regions, flowing down from the north-west. Its tidal limit is situated about 10 miles up the river, near the coal-mines which are worked in the vicinity of this river. From the delta to here it may be denoted as being a river of deposition, although small spurs in some places come down to the river and are to a small extent eroded. At the tidal limit there is a steep rapid or waterfall over hard ferruginous grits and for some distance beyond the river is principally one of erosion, flowing over a succession of these hard grit outcrops, which give rise to rapids and waterfalls. The coalseam which is being worked outcrops in this region.

Above, a few miles north-west of the mines, the river, although smaller,

* Cf. general map of British North Borneo. 
again becomes one of deposition, flowing through a plateau and here splitting up into many tributary branches sluggishly flowing in sinuous courses over the plateau, which is, doubtless, the product of deposition from the erosion of the high hills to the west and north of the mines. These hills include the range seen from the Kalabakang river on the right bank, which forms the watershed between the two rivers, and also a long and lofty ridge, having the aspect of a sierra, caused by alternations of escarpments and dip slopes along the summit-which can be seen towards the interior. Beyond the plateau, the ground gradually rises until spurs are met with ramifying from the high hill system, to which reference has above been made. Here, in the higher altitudes, the numerous streams and torrents constituting the sources of the Silompopon again display erosive action.

The formation in the Silompopon basin consists of a similar Tertiary system, generally dipping gently towards the south, and extending as far as the Kalabakang, which is the next river to consider.

The Kalabakang river, although larger than the Simmenggaris and Serudang or any of their confluents, has, nevertheless, a comparatively narrow basin, large tributaries flowing into it not being in evidence. The Serudang has also a narrow basin in its lower parts, but its basin expands in the interior, as also is the case, on a smaller scale, with that of the Silompopon.

At a distance of about 14 miles up the river from the delta is situated the Tidung village, known by the same name as the riverKalabakang-up to which the river is one of deposition, flowing down in a meandering course.

Beyond the village, outcrops in the river-bed become numerous. The formation from here onwards consists of thick beds of shales and marls with well-defined bedding, which are sharply folded and traversed by numerous small faults. The formation in this district becomes much more disturbed than it is to the south, and the range which occupies the watershed with the Silompopon appears to mark the boundary of the more disturbed area, which extends northwards. Further up, a loose breccia (Fig. 3), in places, overlies these beds uncomformably, being terraces marking a former level of the river, and thus showing the extensive erosion that has been enacted by the river in the upper parts.

About 7 miles beyond the village the first rapids are reached, which are succeeded by others, above which the river becomes more sluggish and deeper, being readily navigable, wandering in meanders far into the interior and trending approximately west-north-west. In its higher reaches, however, a more northerly course is assumed, and its sources descend in a more turbulent form from the high lands which also contain the sources of the Kwamut river-a large tributary of the Kinnabatangan. There are native reports which state that the Serudang, Kalabakang, and $\mathrm{K}$ wamut all rise in the same hill. 
On the north of Cowie harbour a very different formation occurs, consisting of volcanic rocks which rise in hills and mountains, several of which still assume conical forms, thus denoting that volcanic activity took place at a former era in this region, which, though of Tertiary times, occurred subsequently to the period of the Tertiary formation occupying the regions just described. Along the north shore of Cowie harbour, several small rivers and streams pass out which receive the drainage of part of this volcanic hill district. The amount of water passing down these streams is very small. They have, however, extensive tidal portions, but at low tide many of them are almost dry.

At a few miles north-north-west of Tawao is situated a conspicuous and peculiar peak of conical form. It is 608 feet (aneroid) in altitude; it is marked on the chart, however, as being 720 feet. Its rocks form a promontory in the sea called Tanjong Batu (Tanjong-Malay $=$ promontory,

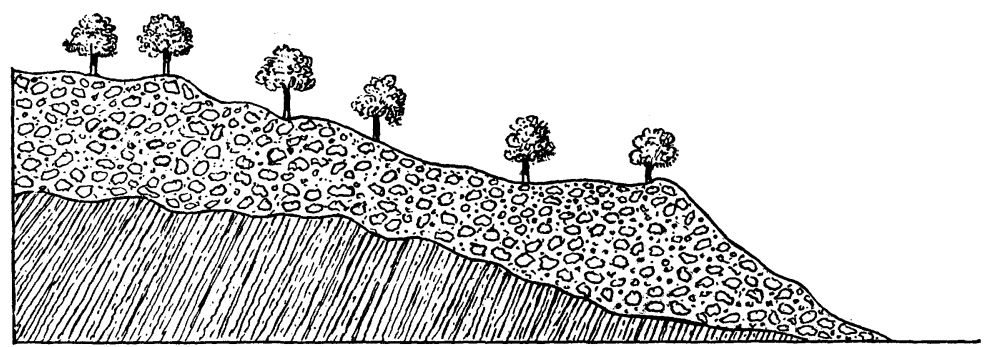

Terrace of Breccia on the bank in the upper reaches of the Kalabakang River FIG. 3.

Batu-Malay = rock), and the same name is given to the hill, although it is named on the maps "Kukusan." This hill exhibits a remarkable conformation. It is composed of volcanic rocks of an andesitic class, masses and huge blocks of which are piled on each other over the whole of the peak and on all sides, giving rise to deep holes and huge caverns in between the blocks. It is, indeed, possible that the hill may be wholly composed of blocks piled up in this manner. The rocks are marked with curious parallel indents, and, in some places, semispherical cavities, and they have a marked sonorous ring when struck. Notwithstanding the nature of the ground, it is covered with quite a dense jungle, the trees taking root amongst and on the top of these blocks, wherever they can obtain a scanty soil. On account of these huge rocks, the hill is almost impregnable, and were it not for the numerous creepers descending from the trees which give assistance in climbing the cliffs, some parts would be impossible to scale; furthermore, belts of dense thorn bush add to the difficulty of ascent. On the east side of Tawao there is another hill, Batu Tenagat, abutting into the sea, which has a similar arrangement of huge blocks. 
Draining the eastern part of this district of volcanic hills, a river, called the Apas, outflows into the sea not far east of Batu Tenagat. This river is remarkable for the presence, in the upper part of its basin, of hot springs depositing calcareous sinter.

It is probable that this region of volcanic rocks extends as far as the vicinity of Darvel bay and the sources of the Segama river, but not much is known concerning this district.

The Segama, by the way, rises some distance to the interior of Darvel bay, and flows in a north-easterly direction, and, passing close to the northeast end of Darvel bay, ultimately flows into the sea on the north of the large promontory of Province Mayne, its delta being continuous with that of the Kinnabatangan.

In connection with this region, it is of interest to notice a reference to it in Posewitz's 'Borneo,'* of which the following is a quotation : "Granite blocks are mentioned as being scattered along the northern shore of Sibuku bay; and not far from the coast, towards the east, is a mountain about 2000 feet high, with gently arching flanks, while in the direction of the river mouth, and in the immediate neighbourhood of the sea, stands a mountain of bold contours and noble proportions, being 3000 to 4000 feet high. Reasoning from analogy, we would expect to find here a rich coral formation, while the granite lying about in blocks points to the presence of the mountain formation." The "granite lying about in blocks" probably refers to the volcanic rocks to which mention has already been made ; there are no rocks resembling the granites in the region, while the coral formation is also absent in this locality. The " mountain about 2000 feet high with gently arching flanks" evidently refers to the Tanjong Batu hill, or Kukusan, mentioned above, and 608 feet in altitude. The volcanic rocks of this region are pyroxene andesites, containing enstatite, augite, and accessory horneblende.

With reference to the various river systems described, and the distribution of drainage, it will be noticed that the basins of the majority of the large rivers expand towards the interior. The peripheral areas, however, must be larger than the internal, and it is necessary to account for their drainage. This is principally adjusted by a large number of minor rivers and streams which flow down all along the coast.

It is of interest briefly to consider whether there have been upward or downward secular movements in the district under discussion, and what influence they may have on the formation of deltas which are so remarkably developed in this region. At first sight, it might appear that secular rise would be favourable to the formation of deltas, for the silt and alluvial materials brought down by the rivers and deposited below the sea-level

* 'Borneo: its Geology and Mineral Resources,' Dr. Theodor Posewitz (trans. lated by Dr. F. R. Hatch), p. 159, 1892. And a reference for the above informa. tion is given in this work to J. Oesterreicher, B. 31, pp. 210-222. 
beyond the margin of the actual deltas would gradually be raised above the sea-level. In this case, however, the waves and currents would probably wash away the materials as fast as they were uplifted, and before there was time for protective vegetation to spring up over them. In the case, however, of secular depression, as the marginal and lower parts of the delta sank beneath the sea, the thick growths of mangrove and nipa would serve to concentrate and catch the silt and sediments brought down by the rivers, while the remains of the submerged vegetation would mingle with the alluvial material to form deposits, upon which fresh vegetation would soon spring up. Moreover, the delta would, at the same time, be carried further backward. In the case of uneven and hilly country, the deltaic deposits would narrow up the valleys, while the more elevated portions would in time become islands-either surrounded by alluvium, or true islands, as the case may be.

Thus it may be concluded that the region under discussion has been, and is, under the influence of secular depression.

The tongues of deltaic formation extending up the valleys, the long tidal limits, and the small streams, nearly dry at low tide, mentioned above as flowing in extensive valleys from the volcanic hill region into the sea on the north coast of Cowie harbour and which could not have eroded their comparatively deep and wide channels at their present level (for a considerable extent below high-water mark), all seem to point to secular depression. Furthermore, in the vicinity of Tawao, the sea is gradually encroaching on cocoanut plantations.

Secular depression may also account for the large islands of Nonuekan and Sebattek which consist of the Tertiary hill formation similar to that of the mainland, and may be regarded as more elevated portions of the former land surface, the intervening depressed areas having become tracts of deltaic alluvium, part of which has become submerged forming the shallow straits which separate these islands from the mainland. Sebattek island is probably a continuation of the range situated to the south of the Kalabakang river and running parallel with its general direction.

Tenelik Island (in the Mouth of the Sibuku). - Tenelek island (Fig. 2) consists of two hills joined by a tract of alluvium, and the recent elevation to which reference has been made as "New hill" is the seaward one of these two hills and overlooks the estuary of the Simmenggaris river. The hill is covered with ferns, which, becoming very dry, periodically ignite, and this circumstance has probably given rise to a native story that phosphorus exists on this hill; nearly the whole of the south side was burnt clear when the writer visited this hill.

The strata dip uniformly towards the west at angles varying up to $45^{\circ}$. They are broken up into more or less rectangular blocks by wide gaping joints. Recent shells occur in pockets in the soil filling these joints on the summit. These shells, now at an altitude of over 100 feet, are similar to the marine organisms which are at the present day denizens 
of the sea, being modern Pacific mollusca-genera Murex (capucinus), Nerita (luxata), and Ostrea. Holes of boring shells, Lithodomis, etc., were found in some of the sandstone beds on the summit.

There are two points north and south of the hill, the north point being the higher, upon which pieces of white hornstone and soft sandstones were strewn, together with numerous small nodules of hard ironstone. Shells could not be found on the north point. On the east side of the hill the succession of strata are exposed in section, dipping generally about $45^{\circ} \mathrm{W}$., and giving the appearance of the rock having been tilted away from the face of the hill and truncated, as well as having been broken up into blocks divided by fissures. The hill presents the aspect of a dip and escarpment ridge, but denudation is, of course, not feasible (to account for this appearance), considering its recent age as indicated by the marine remains on the summit.

Although there was not opportunity for examining Plandok island, which lies a short distance towards the north-west, this island appears to be composed of the same rocks, and to be of a similar formation, and may, possibly, also be of recent upheaval.

It is difficult to conjecture what class of diastrophism has caused the formation of this hill. If it has been originated by a fault, either being the upthrown side or caused by the snapping along an anticlinal axis the northern portion of which has been thrown down, a longer extension of the elevated ridge would be expected, although Plandok island might be a small continuation. That considerable pressure has been connected with this upheaval is shown by the extensive fracturing of the rocks.

Although, perhaps, somewhat irrelevant to the title of this paper, reference may be made, while on the subject of recent upheavals, to a new island which made its appearance on September 21, 1897, on the northwest coast of Borneo, opposite Labuan, in lat. $5^{\circ} 20^{\prime} 30^{\prime \prime}$, long. $115^{\circ} 21^{\prime}$. This upheaval, however, has a very different origin to the elevation described above, having been blown up by natural gas, possibly in combination with seismic activity. The district is notable for mud volcanoes and issues of natural gas in association with traces of petroleum occurring in a disturbed formation. This island has been described by Professor C. Schmidt, who, writing in $1904, *$ and commenting on the rapidity with which the marine erosion was denuding the soft materials, surmised that at the present day probably nothing would remain of this island. This island was visited, however, by the writer in 1908 and 1909, and although the greater part has been washed away, a considerable portion now remains, measuring 210 feet long, 120 feet wide. It is now, however, no longer an island, having become joined to the shore, from which it was never very far, by drifts of sand. It is called Bukit Tumbo (MalayBukit $=$ hill; Tumbo $=$ sprout, rise, or shoot up).

* “ Ueber die Geologie von Nordwest-Borneo und eine daselbst entslandene ' NeueInsel," "Beit:. Geophys., Leipzig, 7, pp. 121-136, pl. VI. (geol. map), 1904, And A. C. 
This upheaval was described, in a report, by Mr. Allard, who was in charge of some drilling operations for petroleum in the neighbourhood at the time, as follows:-

"Halfway between Mempakal and Lambedan, on the 21st of September, in the afternoon, a small island was formed. Some natives were out gathering oysters, and noticed a good many bubbles rising, after which a gradual upheaval took place, and went on all night, forming a hill of about 200 yards by 150 yards, and 50 to 60 feet high. It seems to consist of nothing but slatey-looking clay, with a few sandstones in it, exactly similar to what we have been boring through. It is about 30 yards from the shore, and has evidently been forced up through rocks, as some large portions show where it has been scored and marked by passing out between some hard substance. There was a strong smell of gas when I went to see it on the $22 \mathrm{nd}$, and on picking up some of the rocks they showed signs of a white waxy-looking substance having been forced into crevices, so I think this has been forced up by a pressure of gas below. It is not far from where there are some oil signs on the shore."

In this connection, reference may be made to an account, which has been published in the Journal, * of a similar occurrence, viz. of an upheaval caused by gas in petroliferous regions, which was observed by the commander of a mail steamer as actually taking place off the Arrakan coast of Burma, in September, 1909. This upheaval appears to have great analogies with that of Bukit Tumbo.

\section{TARAWERA ERUPTION AND AFTER.}

By Prof. JAMES PARK, F.G.S. $\dagger$

Mount Tarawera, the scene of the eruption on June 10, 1886, lies in the White island-Taupo volcanic zone, being situated about 27 miles south of the Bay of Plenty. The summit of the mountain before the eruption presented the appearance of a dissected tableland, the northern portion of which was known as Wahanga, the middle portion as Ruawahia, and the southern as Mount Tarawera. The highest point of the mountain rose to the height of 3600 feet above the sea. On the west, Mount Tarawera sloped down to Lake Tarawera, 1040 feet above the sea ; and on the east and south it rose abruptly from the Rotomahana rhyolitic plateau, 1200 feet above the sea.

Fissure-eruptions, both historical and geological, have been distinguished by the quiet emission of floods of lava. The Tarawera outburst

* Geographical Journal, vol. 34, No. 6, December, 1909, p. 690, A. R. W. Handcock.

+ The author accompanied Sir James Hector to the scene of the eruption a few days after the outburst on June 10, 1886; and afterwards visited Tarawera in June, 1900 ; June, 1909 ; and March, 1910. 


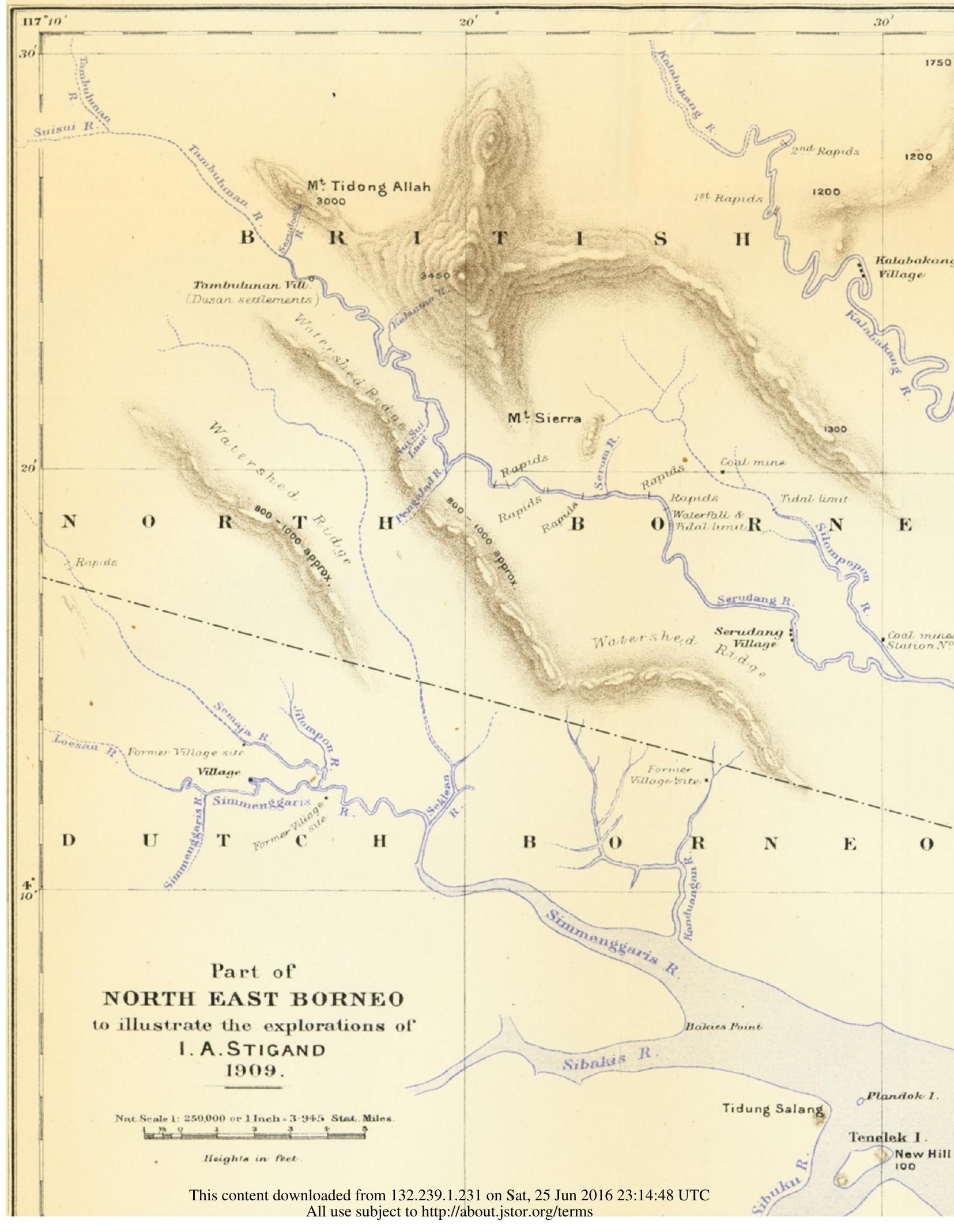




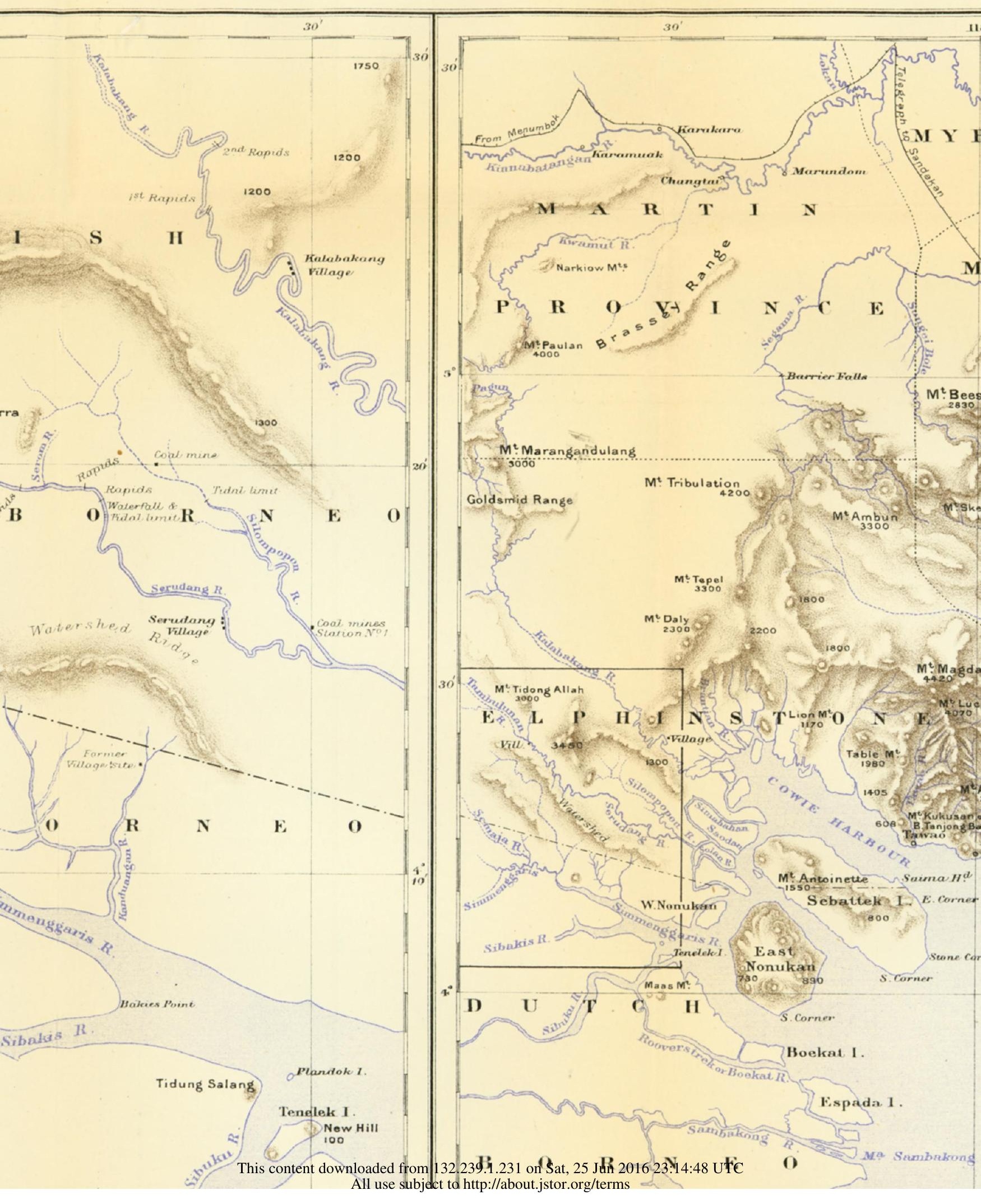




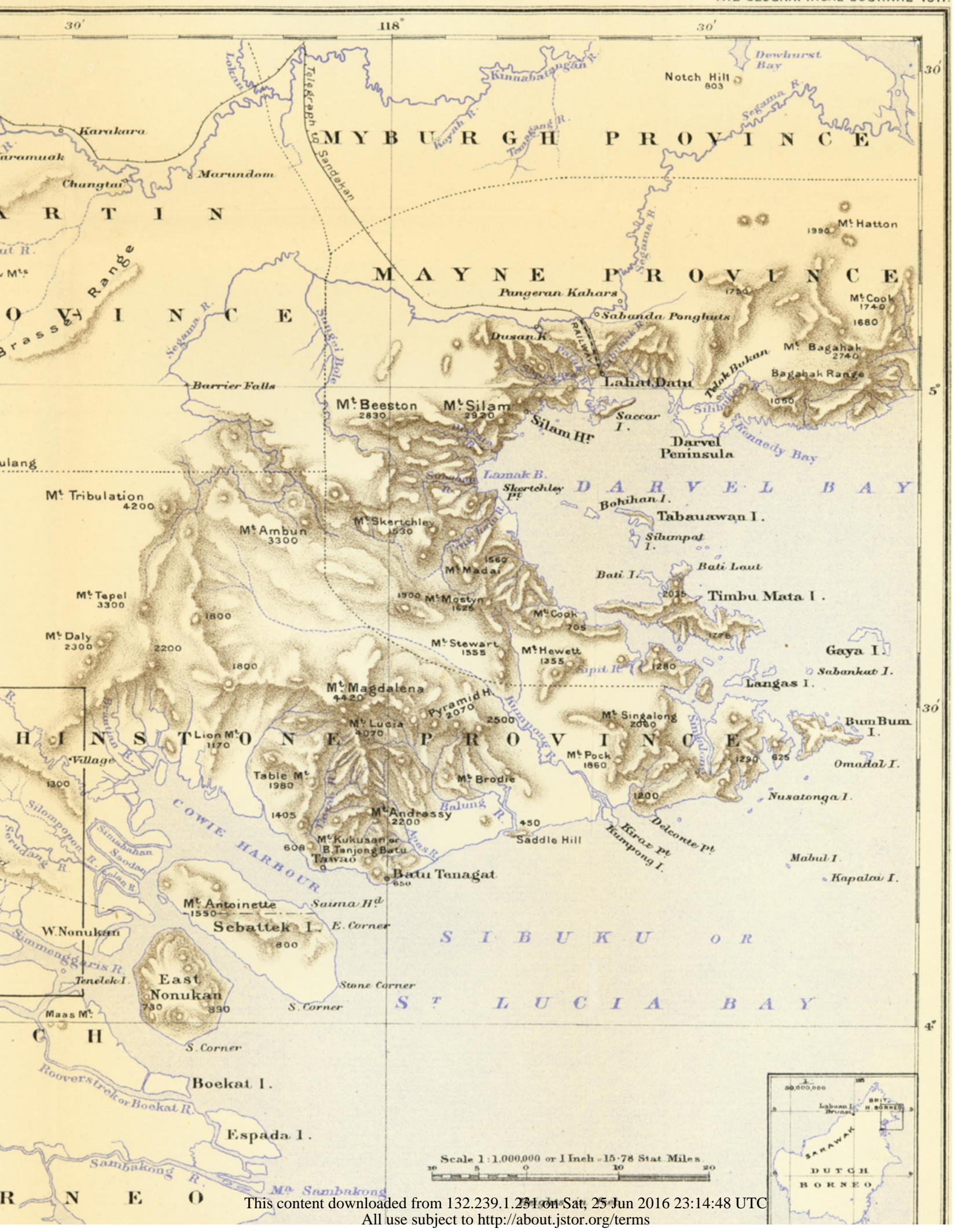




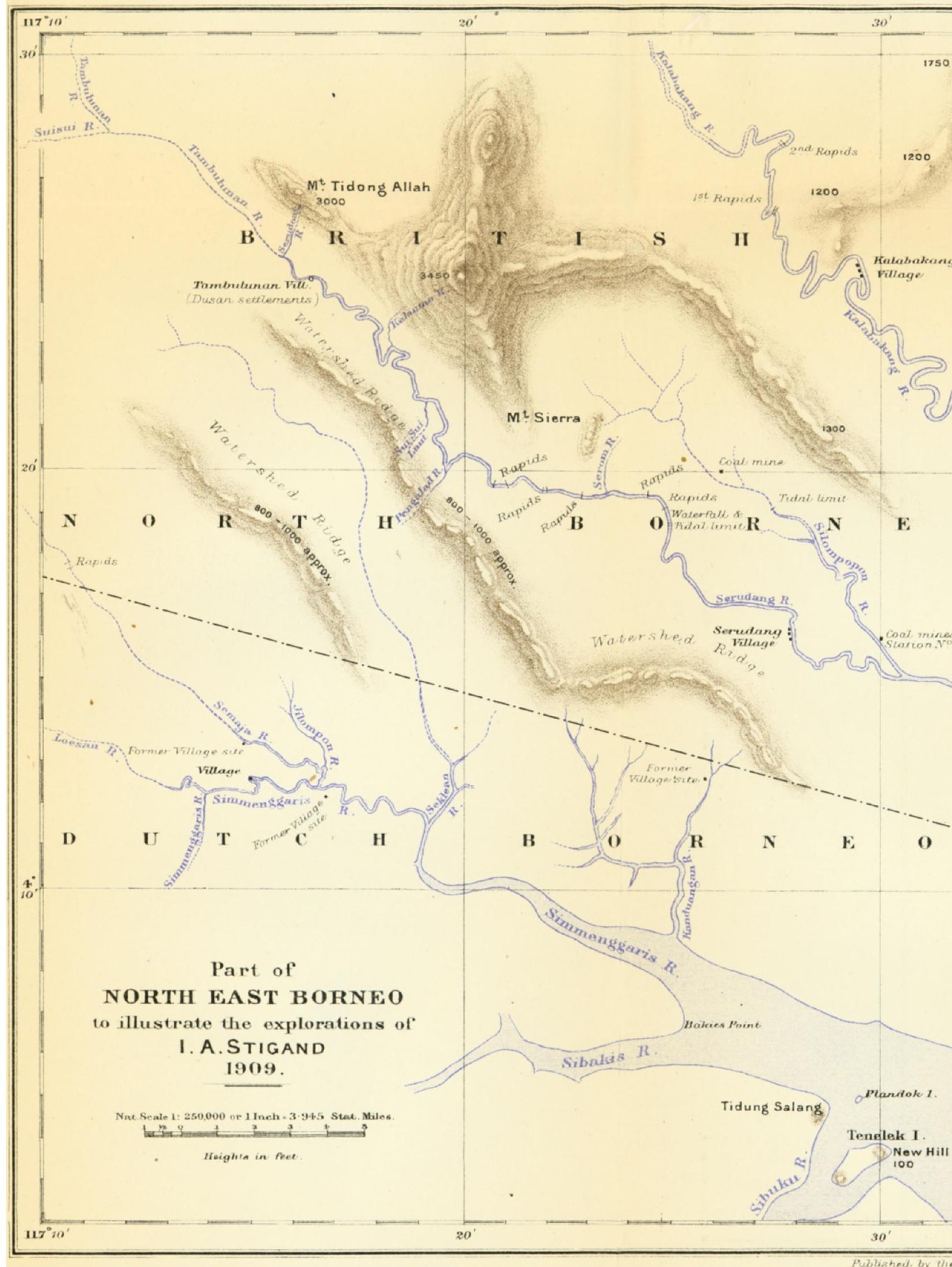

This content downloaded from 132.239.1.231 on Sat, 25 Jun 2016 23:14:48 UTC All use subject to http://about.jstor.org/terms 


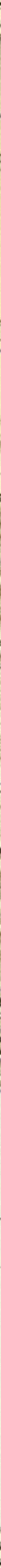

Published. by the Royal Geographical Soried 


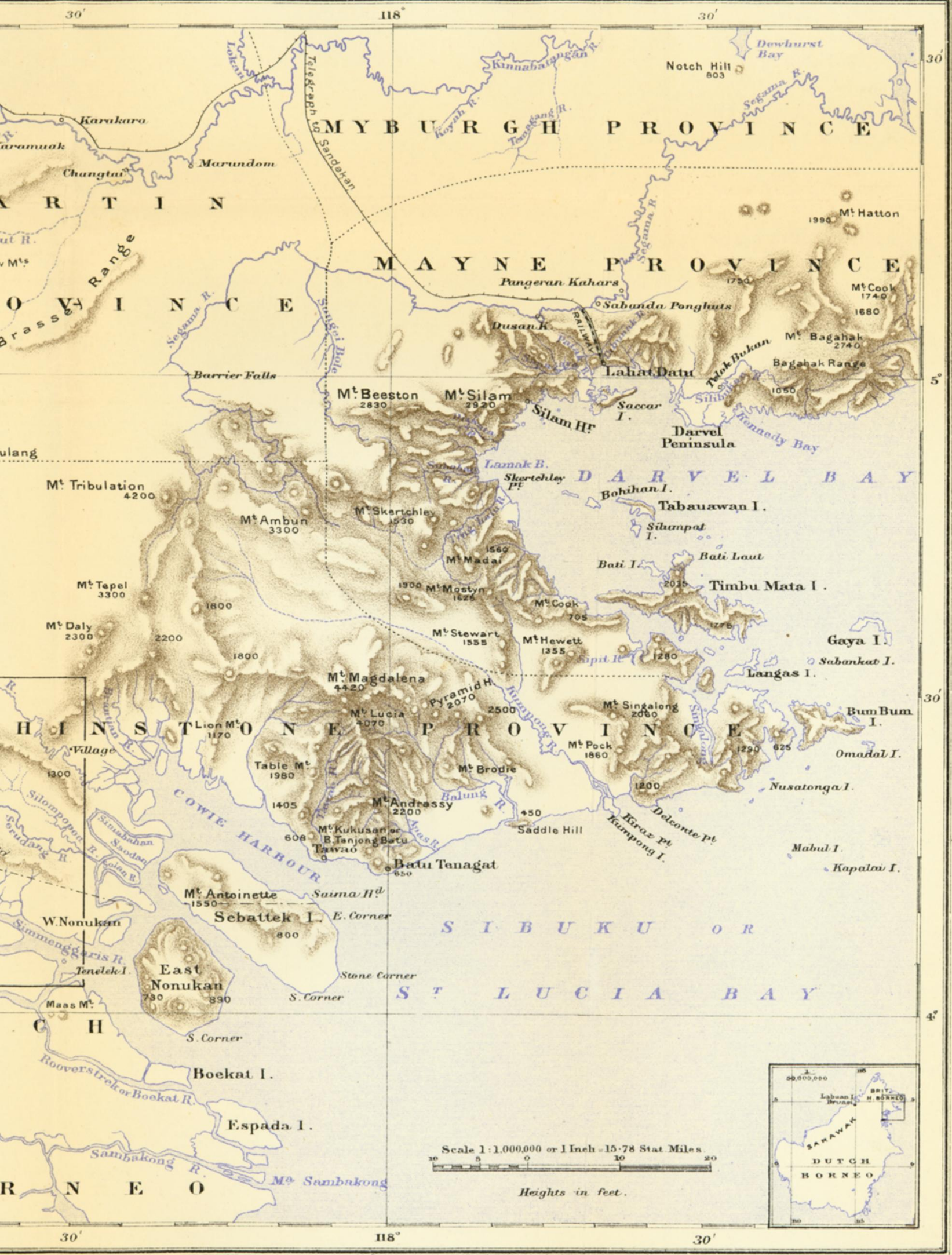

